\title{
AIR POLLUTION ABATEMENT, TECHNOLOGICAL CHANGE, AND RELATIVE PRICES: A REGIONAL INPUT-OUTPUT ANALYSIS
}

\author{
Frank Giarratani and Luther C. Thompson*
}

The foundation for the incorporation of environmental "externalities" in an Input-Output framework was laid by W. Leontief in his by now familiar article, "Environmental Repercussions and the Economic Structure: An Input-Output Approach" (2). In that paper, Leontief showed how one might use the model to deal concretely with some fundamental economic questions about alternatives. To that end, W. H. Miernyk $(4,5)$ has recently used a regional model for West Virginia in an attempt to quantify the effects on output of the change in technology necessary to meet the clean air standards in that region. Using the direct cost estimates of the Miernyk study, this note will examine the impact on relative prices of alternative methods of dealing with the major air pollutants in West Virginia.

Industry efforts to meet federal air quality emission standards necessarily entail large capital expenditures and substantial operating costs. Miernyk is able to account for these direct costs explicitly in the matrix of technical coefficients and the capital matrices of a dynamic regional model. An examination of the West Virginia model's basic equation will allow us to explain Miernyk's method and to show the relationship between the present paper and that effort. In matrix notation, the balance equation for 48 sectors may be written as $(6, \mathrm{p} .63)$ :

$$
X_{t}-A_{t} X_{t}-D X_{t}-B\left(X_{t}-X_{t-1}\right)=Y_{t} .
$$

Solving for $\mathrm{X}_{t}$, we have the equilibrium quantity equation of the dynamic system:

$$
\mathrm{X}_{\mathrm{t}}=\left(\mathrm{I}-\mathrm{A}_{\mathrm{t}}-\mathrm{D}-\mathrm{B}\right)^{-1}\left(\mathrm{Y}_{\mathrm{t}}-\mathrm{BX}_{\mathrm{t}-1}\right),
$$

where: $\mathrm{X}_{\mathrm{t}}=\mathrm{a} 48 \times 1$ vector of total gross outputs in year $\mathrm{t}$,

$\mathrm{A}_{\mathrm{t}}=\mathrm{a} 48 \times 48$ matrix of technical coefficients in year $t$,

$\mathrm{D}^{\mathrm{L}}=$ a $48 \times 48$ matrix of replacement capital coefficients,

$\mathrm{B}=$ a $48 \times 48$ matrix of expansion capital coefficients, and

$\mathrm{Y}_{\mathrm{t}}=\mathrm{a} 48 \times 1$ vector of final demand in year $\mathrm{t}$.

If the fipal demand vector $\left(\mathrm{Y}_{t}\right)$ is held constant and appropriate adjustments are made to the technical coefficient matrix $(\mathrm{A})$ and capital matrices $(\mathrm{B}$ and $\mathrm{D})$ to reflect the changes in technology made necessary by pollution abatement, total gross output before and after the changes may be calculated and compared. The differences between the output vectors represents the direct and indirect cost of 
meeting the clean air standards. The economy must produce more to satisfy a given level of final demand. The method provides a direct means of measuring the magnitude of resources which must be diverted from alternative uses to clean the air.

In the static Leontief model, prices are determined from the technology of the economy. For a given sector, price must be just sufficient to meet the per unit costs of all intermediate inputs and still cover value added (2,p. 266). That is, for the set of $n$ equations $(j=1, \ldots, n)$, assuming a wage rate of one dollar per hour:

$$
p_{j}-\sum_{i=1}^{n} p_{i} a_{i j}=v_{j}
$$

where: $p_{j}=$ the price of one unit of output in the jth sector,

$\mathrm{a}_{\mathrm{ij}}=$ the ith input requirement per unit output of $\mathrm{j}$, and

$v_{j}=$ the value added per unit output of $j$.

In matrix notation:

(p

$$
\left[\begin{array}{llll}
a_{11} & a_{12} & \ldots & a_{1 n} \\
a_{21} & 2_{22} & \ldots & a_{2 n} \\
\cdot & & & \\
\cdot & & & \\
a_{n 1} & a_{n 2} & \ldots & a_{n n}
\end{array}\right]=\left(\begin{array}{llll}
v_{1} & v_{2} & \ldots & v_{n}
\end{array}\right)
$$

or $\mathrm{P}-\mathrm{PA}=\mathrm{V}$,

where: $P=$ the $(1 \times n)$ vector of relative prices $\left(p_{j}\right)$,

$\mathrm{A}=(\mathrm{n} \times \mathrm{n})$ matrix of direct input coefficients $\left(\mathrm{a}_{\mathrm{ij}}\right)$, and

$\mathrm{V}=$ the $(1 \times \mathrm{n})$ vector of value added coefficients $\left(\mathrm{v}_{\mathrm{j}}\right)$.

Solving this system of equations for equilibrium prices we obtain:

$$
\mathrm{P}=\mathrm{V}(\mathrm{I}-\mathrm{A})^{-1}
$$

The price of the jth sector may then be expressed as a function of the direct and indirect value added requirements per unit of output,

$$
p_{j}=\sum_{i=1}^{n} v_{i} z_{i j}
$$

where $z_{i j}$ is the $i$, jth element of $(I-A)^{-1}$. The elements $z_{i j}$ are the well-known input-output multipliers measuring the direct and indirect input required of the 
ith sector per unit delivery to final demand in sector $\mathrm{j}$. As defined earlier, $\mathrm{v}_{\mathrm{i}}$ is the value added coefficient of the ith sector. The element $v_{i} z_{i j}$ may then be interpreted as the amount of the ith sector's value added embodied directly and indirectly in one unit of j's output, the price, $p_{j}$, reflecting the value added contribution of all inputs used in the production of $j$. Price may be considered an index of primary factor content, embodied value added. [See Leontief (1) for a complete and rigorous mathematical description of this aspect of the input-output model, and Leontief (2) for a more intuitive description.]

Just as the quantity relation may be used to estimate the direct and indirect impact of pollution abatement on output, this price relation-given the assumption that prices in each sector equal unit costs - may be used to show the potential impact on relative prices. In this case, both the value added vector and the $A$ matrix must be changed to reflect abatement expenditures. Unlike the dynamic quantity equation, the capital matrices are not explicit in this relation. Only changes in operating expenses, as reflected by changes in the $\mathrm{a}_{\mathrm{ij}} \mathrm{s}$ and $\mathrm{v}_{\mathrm{i}} \mathrm{s}$, are taken into account in determining the effect on relative prices.

The West Virginia model has as one particular feature a technical coefficient matrix that changes over time. The matrix of technical coefficients for $1965\left(\mathrm{~A}_{65}\right)$ was based on survey data, and a second matrix for $1975\left(\mathrm{~A}_{75}\right)$ was projected using the "best practice" approach (6, p. 21). On the basis of a linear interpolation between the $A_{65}$ and $A_{75}$ matrices, technical coefficient matrices for the intervening years are generated and used for comparative static and dynamic projections. The model also projects a vector of primary labor coefficients for $1975\left(\mathrm{a}_{075}\right)$, taking into account estimates of productivity increases for each sector. Both the $\mathrm{A}_{75}$ and its associated value added vector, $\mathrm{V}_{75}$, are used to obtain relative prices in this note.

Significant work has been done by Leontief and Ford (3) toward the empirical implementation of the theoretical framework set out in Leontief's earlier work: As part of their effort, the price effects of four air pollution control strategies are estimated for the 1963 national input-output model. Information concerning the technical requirements of the pollution abatement activities was not available at the time the article was written, and price effects were calculated on the basis of estimated changes in the value added coefficients only. In Leontief and Ford's notation (3, p. 24),

$$
\begin{aligned}
& \mathrm{P}^{\mathrm{k}}=\mathrm{V}^{\mathrm{k}}\left(\mathrm{I}-\mathrm{A}^{63}\right)^{-1} \text { and } \\
& \mathrm{V}^{\mathrm{k}}=\left(\mathrm{v}_{1}^{63}, \mathrm{v}_{2}^{63}, \mathrm{v}_{3}^{63}, \ldots, \mathrm{v}_{\mathrm{m}}^{63}\right)+\left(\mathrm{v}_{1}^{\mathrm{k}}, \mathrm{v}_{2}^{\mathrm{k}}, \mathrm{v}_{3}^{\mathrm{k}}, \ldots, \mathrm{v}_{\mathrm{m}}^{\mathrm{k}}\right),
\end{aligned}
$$

where $v_{i}^{k}$ is the increment to the value added coefficient of industry i resulting from pollution control strategy $\mathrm{k}$. As the authors point out, price changes calculated in this manner must necessarily be positive. Using a comparable technique and estimates of incremental labor costs from Miernyk's study, the price effects of pollution abatement for selected West Virginia industries are compared with the Leontief-Ford results in Table 1.

The sectors presented were chosen on the basis of their relative importance in the West Virginia economy. The differences between national and regional price 
effects are as a whole not significant, for the most part being of the order of .5\% or less. The largest relative difference is in West Virginia Sector 46, Electric companies and systems, where the increase is $5.5 \%$ greater than the national. It should be recognized that these differences may be due, in part, to the difficulty of estimating exactly comparable incremental value added coefficients and the lack of direct correspondence between national and regional sectors. Furthermore, as indicated in Table 1, the Leontief-Ford prices were calculated on the basis of the 1963 national table, while the prices calculated for this paper have as a base the 1975 West Virginia projected coefficients.

TABLE 1

PRICE EFFECTS

(price before pollution abatement $=1,00000$ )

\begin{tabular}{|c|c|c|c|}
\hline WEST VIRGINIA & & & LEONTIEF/FORD NATIONAL \\
\hline 1. Agriculture & 1.00146 & 1.00612 & 19. Other agriculture products \\
\hline 2. Coal Mining (underground) & 1.00399 & 1.00504 & 13. Coal Mining \\
\hline 3. Coal Mining (strip \& auger) & 1.00121 & 1.00504 & 13. Coal Mining \\
\hline 4. Petroleum \& natural gas & 1.00060 & 1.00158 & $\begin{array}{l}\text { 24. Crude petroleum \& natural } \\
\text { gas }\end{array}$ \\
\hline 17. Chemicals & 1.00529 & 1.00651 & 7. Industrial chemicals \\
\hline 19. Glass & 1.00569 & 1.00266 & 50. Glass \& glass products \\
\hline 20. Stone \& clay products & 1.00483 & 1.00431 & 51. Stone \& clay products \\
\hline 21. Primary metal products & 1.00719 & 1.01914 & 57. Iron \& steel forgings \\
\hline 46. Electric companies \& systems & 1.13598 & 1.07318 & 2. Electric utilities \\
\hline 17. Gas companies \& systems & 1.00095 & 1.00106 & 87. Gas utilities \\
\hline
\end{tabular}

*Source: Leontief/Ford, page 22.

In Leontief's theoretical framework, his suggestion for calculating the price effects of various pollution abatement strategies is to add a new anti-pollution industry to the model, generating new equilibrium prices (2, p. 268). The data necessary to do this are not available for the West Virginia model, but estimates of ihe effects of air pollution abatement on existing technology have been made by Miernyk and Sears (5). This study, conducted over a period of more than two years, nvolved the collection of data on the direct costs associated with the abatement of ndustrial emissions from stationary sources in West Virginia. The cost estimates Nere based on information obtained from visits by staff members to plants in each ;ector significantly affected by the federal air pollution standards and supplemented by the best available data from previously published sources. These stimates have been used to adjust the technical coefficients of 16 of the 48 sectors of the West Virginia input-output model. Considering these incremental costs due :o air pollution abatement, new price vectors given by,

$\widetilde{\mathrm{P}}=\widetilde{\mathrm{V}}\left(\mathrm{I}-\widetilde{\mathrm{A}}_{75}\right)^{-1}$

nay be generated. The tilda $(\sim)$ means that adjustments have been made in the sreviously defined vector or matrix on the basis of the incremental cost estimates lue to abatement. 
The results, presented in Table 2, represent the price effects of particulat pollution abatement and two alternatives for sulfur dioxide pollution abatement Although most manufacturing sectors are directly affected to some extent by particulate emission standards, sixteen were most significantly affected. It i usually the case that more than one control method was available for each sector Decisions as to which technology would be adopted were made on the basis of cos and efficiency. Three industries-Chemicals (Sector 17), Primary metals (Secto 21), and Electric utilities (Sector 46)-have sulfur dioxide emission problems Three methods for removing sulfur oxides are considered by Miernyk and Sear (5). The first, physical (deep) coal cleaning, is technically feasible at the presen time. It is the least costly and least effective alternative. Two other processes-th Myers-TRW (Thompson-Ramo-Woolridge) chemical cleaning and sulfur-oxid flue gas scrubbing-are not presently feasible but may become operational withir a few years. These methods have larger direct costs and are considerably mor efficient than deep coal cleaning.

\section{TABLE 2}

\section{PRICE EFFECTS OF AIR POLLUTION ABATEMENT} $(1975=1.00000)$

\begin{tabular}{l|c|c|c}
\hline & $\begin{array}{c}\text { Particulate } \\
\text { Matter } \\
\text { Abatement }\end{array}$ & $\begin{array}{c}\text { Sulfur } \\
\text { Dioxide } \\
\text { Alternative } \\
\text { I }\end{array}$ & $\begin{array}{c}\text { Sulfur } \\
\text { Dioxide } \\
\text { Alternative } \\
\text { II }\end{array}$ \\
\hline 1. Agriculture & 1.00022 & 1.00021 & 1.00212 \\
2. Coal mines & $1.00001^{*}$ & 1.00005 & 1.00518 \\
3. Coal (strip \& auger) & 1.00000 & 1.00008 & 1.00203 \\
4. Petroleum \& natural gas & 1.00028 & 1.00014 & 1.00165 \\
5. All other mining & 1.00034 & 1.00027 & 1.00310 \\
6. Building contractors & 1.00377 & 1.00376 & 1.00571 \\
7. Non-building contractors & 1.00206 & 1.00163 & 1.00308 \\
8. Special contractors & 1.00258 & 1.00260 & 1.00350 \\
9. Food products & $1.00023^{*}$ & 1.00009 & 1.00439 \\
10. Dairies & $1.00014^{*}$ & 1.00009 & 1.00149 \\
11. Bakeries & $1.00014^{*}$ & 1.00003 & 1.00794 \\
12. Beverages & $1.00096^{*}$ & 1.00092 & 1.00203 \\
13. Apparel \& accessories & 1.00007 & 1.00007 & 1.00126 \\
14. Logging \& sawmills & 1.00014 & 1.00013 & 1.00232 \\
15. Furn. \& wood fabrication & 1.00023 & 1.00020 & 1.00162 \\
16. Printing \& publishing & 1.00038 & 1.00039 & 1.00089 \\
17. Chemicals & $1.00512^{*}$ & $1.00126^{*}$ & $1.00320^{*}$ \\
18. Petroleum products & $1.00236^{*}$ & 1.00021 & 1.00201 \\
19. Glass & $1.00042^{*}$ & 1.00035 & 1.00651 \\
20. Stone \& clay products & $1.00085^{*}$ & 1.00052 & 1.00572 \\
21. Primary metals & $1.11274^{*}$ & $1.11534^{*}$ & $1.11675^{*}$ \\
22. Fabricated metals & $1.01235^{*}$ & 1.01233 & 1.01401 \\
23. Machinery (except electric) & $1.00460^{*}$ & 1.00453 & 1.00575 \\
24. Electric machinery & $1.01651^{*}$ & 1.01670 & 1.02193 \\
25. Transportation equipment & $1.00757^{*}$ & 1.00759 & 1.00902 \\
26. Instruments \& products & $1.00239^{*}$ & 1.00008 & 1.00052 \\
27. All other manufacturing & 1.00047 & 1.00045 & 1.00173 \\
28. Restaurants \& bars & 1.00006 & 1.00005 & 1.00744 \\
\hline & & & 1.005 \\
\hline
\end{tabular}




\begin{tabular}{|c|c|c|c|}
\hline & $\begin{array}{c}\text { Particulate } \\
\text { Matter } \\
\text { Abatement }\end{array}$ & $\begin{array}{c}\text { Sulfur } \\
\text { Dioxide } \\
\text { Alternative } \\
\text { I }\end{array}$ & $\begin{array}{c}\text { Sulfur } \\
\text { Dioxide } \\
\text { Alternative } \\
\text { II }\end{array}$ \\
\hline $\begin{array}{l}\text { 29. Wholesale trade } \\
\text { 30. Retail food stores } \\
\text { 31. Auto service stations } \\
\text { 32. All other retail } \\
\text { 33. Banking } \\
\text { 34. Other finance } \\
\text { 35. Insurance agents } \\
\text { 36. Real estate } \\
\text { 37. All other FIRE } \\
\text { 38. Hotels \& lodgings } \\
\text { 39. Medical \& legal services } \\
\text { 40. Educational services } \\
\text { 41. All other services } \\
\text { 42. Railroads } \\
\text { 43. Trucking \& warehousing } \\
\text { 44. All other transportation } \\
\text { 45. Communications } \\
\text { 46. Electrical systems } \\
\text { 47. Gas systems } \\
\text { 48. Water \& sanitary services }\end{array}$ & $\begin{array}{l}1.00005 \\
1.00006 \\
1.00006 \\
1.00008 \\
1.00003 \\
1.00009 \\
1.00001 \\
1.00041 \\
1.00004 \\
1.00015 \\
1.00006 \\
1.00039 \\
1.00027 \\
1.00068 \\
1.00025 \\
1.00082 \\
1.00009 \\
1.00013^{*} \\
1.00006 \\
1.00066\end{array}$ & $\begin{array}{l}1.00004 \\
1.00006 \\
1.00005 \\
1.00008 \\
1.00002 \\
1.00009 \\
1.00001 \\
1.00041 \\
1.00003 \\
1.00015 \\
1.00004 \\
1.00038 \\
1.00025 \\
1.00068 \\
1.00024 \\
1.00082 \\
1.00008 \\
1.00012 \\
1.00005 \\
1.00054\end{array}$ & $\begin{array}{l}1.00308 \\
1.00484 \\
1.00223 \\
1.00285 \\
1.00144 \\
1.00069 \\
1.00022 \\
1.00177 \\
1.00093 \\
1.00833 \\
1.00097 \\
1.00245 \\
1.00184 \\
1.00142 \\
1.00134 \\
1.00185 \\
1.00119 \\
1.14635 \% \\
1.00048 \\
1.00884\end{array}$ \\
\hline
\end{tabular}

* Sector directly affected by air pollution abatement

$\mathrm{SO}_{2}$ Alternative I represents the price effects of deep coal cleaning in Sectors 17, 21, and 46, while $\mathrm{SO}_{2}$ Alternative II considers the effects of deep coal cleaning in Sectors 17 and 21, as well as the TRW and scrubbing techniques in Sector 46. The only sector whose relative price is significantly affected by $\mathrm{SO}_{2}$ Alternative I is Primary metal products (Sector 21). The increment in operating expenses due to air pollution abatement in that sector is large relative to the total outlay for all sectors. Additionally, the incremental operating costs for that sector are large relative to its total operating costs as compared with other sectors.

$\mathrm{SO}_{2}$ Alternative II, replacing deep coal cleaning with the more effective TRW and $\mathrm{SO}_{2}$ scrubbing techniques in Sector 46, Electric utilities, shows a substantial price increase in that sector as well as large indirect increases in linked sectors. The increase in relative prices from $\mathrm{SO}_{2}$ Alternative I to $\mathrm{SO}_{2}$ Alternative II may be attributed to the increase in direct operating costs in Electric utilities, since the cost estimates for Chemicals and Primary metals are identical between alternatives.

Although the data used in this analysis are particular to the state of West Virginia, these results are of general interest in two respects. First, the calculations summarized in Table 1 above represent partial evidence that the price effects of air pollution abatement may not be significantly different at the regional and national levels. Second, the abatement techniques considered are of current interest nationally for the abatement of the two pollutants considered, particulate matter and sulfur dioxide. It should be emphasized, however, that this analysis is within a static context. As such, the impact on relative prices of the capital requirements of these abatement alternatives is not considered. 


\section{REFERENCES}

(1.) W. Leontief, The Structure of American Economy, 1919-1939, 1951, Oxford University Press, New York

(2.) W. Leontief, "Environmental Repercussions and the Economic Structure: An Input-Output Approach", Review of Economics and Statistics, Vol. LII, No. 3 (August, 1970), pp. 262-271.

(3) W. Leontief and D. Ford, "Air Pollution and the Economic Structure: Empirical Results of Input-Output Computations", Input-Output Techniques, A. Brody and A. P. Carter (eds.), 1972, North-Holland Publishing Company, pp. 9-30.

(4.) W. H. Miernyk, "A Regional Input-Output Pollution Abatement Model", IEEE Transactions on Systems, Man and Cybernetics, Vol. SMC-3, No. 6 (November, 1973), pp. 575-577.

(5.) W. H. Miernyk and John Sears, Air Pollution Abatement and Regional Economic Development, 1974, D. C. Heath. Lexıngton. Mass.

(6.) W. H. Miernyk et al., 1970, Simulating Regional Economic Development, D. C. Heath, Lexington, Mass. 